\title{
JUDICIALIZAÇÃO DA POLÍTICA E PODER LEGIFERANTE: A ILEGITIMIDADE DA INTERFERENCIA DO SUPREMO TRIBUNAL FEDERAL NA POLÍTICA NACIONAL
}

JUDICIALIZATION OF POLITICS AND LEGISLATIVE POWER: THE ILLEGITIMACY OF FEDERAL SUPREME COURT INTERFERENCE IN NATIONAL POLITICS

JUDICIALIZACIÓN DE LA POLÍTICA Y EL PODER LEGIFERANTE: LA ILEGITIMIDAD DE LA INTERFERENCIA DEL SUPREMO TRIBUNAL FEDERAL EN LA POLÍTICA NACIONAL

\section{Claudio Ladeira de Oliveira ${ }^{1}$}

\section{Suellen Moura²}

Licença CC BY:

Artigo distribuído sob os termos Creative Commons, permite uso e distribuição irrestrita em qualquer meio desde que 0 autor credite a fonte original.

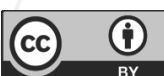

\begin{abstract}
Resumo: $O$ presente artigo analisa a judicialização da política como causa e consequência de uma postura ostensiva de verificação política da legislação, sustentando um descompasso normativo e empírico da legitimidade da legiferaçãojudicial eilustrando a posição de proeminência do Supremo Tribunal Federal no controle da política nacional com exposição de exemplos recentes no campo da representação política.
\end{abstract}

Palavras-chave: Judicialização da política; Legitimidade de legiferação; Representação política.

Abstract: This article analyzes the judicialization of politics as the cause and consequence of an ostensive posture of political verification of the legislation, supporting the normative and empirical mismatch of the legitimacy of judicial lawmaking and illustrating the prominent position of the Supreme Federal Tribunalwhen it comes to the control of national policy, giving some recent examples from the area of political representation.

Key-words: Judicialization of politics; Legitimacy of Legislation; Political representation.

\footnotetext{
1 Doutor em Direito pela Universidade Federal de Santa Catarina (UFSC). Professor adjunto da Faculdade de Direito da Universidade Federal de Santa Catarina (UFSC). Coordenador do Grupo de Pesquisa em Constitucionalismo Político da Universidade Federal de Santa Catarina (UFSC). Contato: claudioladeira@hotmail.com.

2 Mestranda no Programa de Pós-graduação em Direito da Universidade Federal de Santa Catarina (PPGD/UFSC). Pesquisadora no Grupo de Pesquisa em Constitucionalismo Político da Universidade Federal de Santa Catarina (UFSC). Bolsista CAPES. Contato: spmoura14@gmail.com.
} 
Resumen: El presente artículo analiza la judicialización de la política como causa y consecuencia de una postura ostensible de verificación política de la legislación, sosteniendo un descompaso normativo y empírico de la legitimidad de la legiferación judicial e ilustrando la posición de prominencia del Supremo Tribunal Federal en el control de la política nacional con exposición de ejemplos recientes en el campo de la representación política.

Palabras clave: Judicialización de la política; Legitimidad de legiferación; Representación política.

\section{INTRODUÇÃO}

A partir de revisão bibliográfica sobre o tema e exemplos recentes do contexto político brasileiro, o presente artigo pretende expor que a judicialização da política é, em algum grau, um fato incontornável das sociedades modernas - principalmente pelo desenho institucional que observamos nas democracias contemporâneas a partir do processo de constitucionalização do direito e na adoção de jurisdiçães constitucionais -, consistindo um caminho de mão dupla: se, por um lado, ela é a causa da confiança em juízes e tribunais em uma postura ostensiva de verificação política da legislação; por outro, ela também é o encorajamento por parte do povo e seus legisladores, do crédito a atuações judiciais em vista do descrédito das posturas observadas nas instâncias políticas.

Em um segundo momento, exploramos a associação do aspecto político alinhavado inevitável e justificadamente à prática da legiferação, destacando que, se tanto o povo como as instâncias políticas e juristas compartilham, em alguma medida - dada a assimetria de informações acerca dos embates políticos ${ }^{3}$ - essa concepção de supremacia de um tribunal constitucional (jurídico, imparcial, imune às pressões políticas) em detrimento de instituições políticas (parcial, política, partidária), então há boas razões que nos permitem identificar uma distorção na percepção do papel mais ou menos político desempenhado por essas instituições.

Essecontextonos direcionaparaumterceiropontonoqual nosconcentraremos: o descompasso no plano normativo - quando acreditamos que, idealmente, é mais confiável que tribunais superiores e juízes, que possuem uma alta parcela de independência e frágil responsabilização de suas posturas (accountability), resolvam questões morais e/ou filosoficamente controvertidas nas quais todos

3 Para aprofundamento, consultar: HOLMES, Stephen. Constituições e constitucionalismo. In: ASENSI, Felipe, PAULA, Daniel Giotti de (Orgs.). Tratado de Direito Constitucional, vol. 2. Rio de Janeiro: Elsevier, 2014, 577-608. 
os cidadãos possuem interesse em jogo - e no plano real da dinâmica do corpo judicial, uma vez que a estruturação das hierarquias organizacionais do sistema judiciário reflete um contexto no qual tribunais interagem com seu ambiente político, muitas vezes, de forma bastante partidária, uma vez que ao exercer a função de legislador positivo um tribunal não está imune à pressões políticas.

A seguir, analisaremos a institucionalização dos tribunais constitucionais e a forma de estruturação dos sistemas judiciários como fatores que interferem no papel expansivo das Cortes na verificação política da legislação. A expansão do poder judicial também estimula a ação de grupos políticos canalizando as pressões no judiciário e explorando todos os canais de influência disponíveis. Resulta desse contexto que a exposição e a limitação do exercício da influência política no poder judiciário decorrem também da verificação do poder judicial.

Por fim, ilustraremos a expansão da capacidade do Supremo Tribunal Federal para interferir diretamente em questões que, até então, eram consideradas de natureza essencialmente política, especialmente no campo da representação política, indicando que o desenho institucional da Corte brasileira insere o Supremo em posição proeminente de controle da política pela jurisdição constitucional, gerando conflitos entre o Poder Judiciário e o Congresso Nacional e desencadeando a fragilidade do sistema representativo em responder às expectativas sobre ele colocadas.

\section{JUDICIALIZAÇÃO DA POLÍTICA: UMA VIA DE MÃO DE DUPLA}

A expressão "judicialização da política" é bastante controvertida. C. Neal Tate e Torbjörn Vallinder ${ }^{4}$, em trabalho precursor considerado um clássico sobre o tema, sustenta que é possível apontar dois grandes sentidos para essa expressão: expansão da seara dos tribunais ou dos juizes à custa de políticos e/ ou administradores ou difusão de métodos decisórios judiciais da seara judicial propriamente dita. Ou seja, "poderíamos dizer que a judicialização envolve, essencialmente, transformar algo em alguma forma de processo." ${ }^{5}$ Nesse aspecto,

\footnotetext{
4 TATE, C. Neal; VALLINDER, Torbjorn. The Global Expansion of Judicial Power. New York: New York University Press, 1995.

5 VALLINDER, Torbjorn. A judicialização da política: um fenômeno mundial. In: MOREIRA, Luiz (Org.). Judicialização da Política. 1. ed. São Paulo: 22 Editorial, 2012, p. 15.
} 
o judicial review das ações do legislativo e do executivo compõe uma forma importante de sobrepor o poder judiciário sob os outros poderes.

Em estudo sobre os sentidos emprestados ao termo, Débora Alves Maciel e Andrei Koerner destacam que "judicialização da política" e "politização da justiça" seriam expressões correlatas, as quais enunciariam os efeitos da expansão do Poder Judiciário no processo decisório das democracias contemporâneas. Nesse sentido, a ideia de judicialização envolve as dimensões formal e substancial do exercício das funções judiciais, pois "se na idéia da política judicializada estão em evidência modelos diferenciais de decisão, a noção de politização da justiça destaca os valores e preferências políticas dos atores judiciais como condição e efeito da expansão do poder das Cortes". Concluem que, de um modo geral, a expressão é utilizada em sentido normativo, tanto em relação ao papel atual dos agentes do sistema judicial, assim como em relação a propostas sobre a extensão adequada do seu papel na democracia brasileira6

Ran Hirschl ${ }^{7}$ explica a judicialização da política como umas das principais consequências do contexto da supremacia constitucional, em que o aumento contínuo da confiança nos meios jurisdicionais transformou tribunais superiores nacionais em influentes órgãos políticos de tomada de decisão ${ }^{8}$. Munidos do intrumento do judicial review, os tribunais superiores são chamados a resolver um amplo leque de questões. Esse fenômeno estabeleceu o primado da supremacia da interpretação judicial sobre a lei, conferindo progressiva supremacia política à interpretação realizada pelo Judiciário. Para o autor, a judicialização da política tornou-se um fenômeno mundial, bem como alcançou patamares megapolíticos, revelando-se uma realidade compartilhada por muitos países ao redor do mundo?,

6 MACIEL, Débora Alves; KOERNER, Andrei. Sentidos da judicialização da política: duas análises. Disponível em: <http://www.scielo.br/pdf/\%0D/ln/n57/a06n57.pdf>. Acesso em: 11 dez. 2017.

7 HIRSCHL, Ran. A judicialização da megapolítica e o surgimento dos tribunais políticos. In: MOREIRA, Luiz (Org.). Judicialização da Política. 1. ed. São Paulo: 22 Editorial, 2012, p. 28.

8 "Os exemplos incluem o destino da presidência norte-americana, a guerra na Tchetchênia, a agitação política quase constante no Paquistão, a cidadania multicultural na Europa Ocidental, o lugar da Alemanha na UE, dilemas de justiça de transição no mundo pós-comunismo tanto quanto da América Latina pós-autoritarismo e na África do Sul pós-apartheid, o status de populações indígenas na Austrália e na Nova Zelândia, o futuro político do Quebec e da Federação Canadense, a eminência da lei Shari'a no Egito, a natureza secular do sistema político na Turquia, ou a definição fundamental de Israel como 'Estado judeu e democrático' e a correspondente questão 'quem é judeu?'”. HIRSCHL, Ran. A judicialização da megapolítica e o surgimento dos tribunais políticos. In: MOREIRA, Luiz (Org.). Judicialização da Política. 1. ed. São Paulo: 22 Editorial, 2012, p. 28.

9 HIRSCHL, Ran. A judicialização da megapolítica e o surgimento dos tribunais políticos. In: MOREIRA, Luiz (Org.). Judicialização da Política. 1. ed. São Paulo: 22 Editorial, 2012. 
especialmente no período pós-guerra, marcado pela universalização dos tribunais constitucionais e pela utilização do recurso ao controle de constitucionalidade.

John Ferejohn, por sua vez, sinaliza três modos nos quais o judiciário vem desempenhando papéis importantes em relação ao legislativo. Primeiramente, apontamos para uma imposição de limites ao poder das intituições legislativas na medida em que "os tribunais têm-se tornado cada vez mais capazes e dispostos a limitar e regular o exercício da autoridade parlamentar"10. Em um segundo enfoque, destaca que "as salas de audiência passaram a servir cada vez mais de lugar para a realização de política substantiva"11. Por fim, "os juizes têm-se mostrado cada vez mais dispostos a regular a conduta da própria atividade política (...) ao criar e aplicar padrões de comportamentos aceitáveis para grupos de interesse, partidos políticos e autoridades tanto eleitas quanto nomeadas". ${ }^{12}$

Oscar Vilhena Vieira ${ }^{13}$ pontua que, para muitos constitucionalistas, o deslocamento da autoridade do sistema representativo para o judiciário não é um processo recente e compreende uma consequência do avanço das denominadas constituições rígidas, com sistemas de controle de constitucionalidade, de origem norte-americana. Contudo, a expansão da autoridade judicial é mais perceptível quando da adoção de constituições mais ambiciosas. Ou seja, as constituições contemporâneas ${ }^{14}$ são desconfiadas do legislador, confiando ao judiciário a função de guardião da constituição e ao legislativo e ao executivo apenas a função de implementação da vontade constituinte. Não obstante, a hiper-constitucionalização da vida contemporânea para Vieira constitui a consequência da desconfiança na democracia e não a sua causa, de modo que "uma vez realizada a opção institucional de ampliação do escopo das constituições e de reforço do papel do judiciário, como guardião dos compromissos constitucionais, isto evidentemente contribuirá para o amesquinhamento do sistema representativo" ${ }^{15}$.

10 FEREJOHN, John. Judicializando a Política, Politizando o Direito. In: MOREIRA, Luiz (Org.). Judicialização da Política. 1. ed. São Paulo: 22 Editorial, 2012, p. 63.

11 Ibidem, p. 63.

12 Ibidem, p. 63.

13 VIEIRA, Oscar Vilhena. Supremocracia. In: Revista Direito GV, São Paulo, jul-dez de 2008, pp. 441-464.

14 "Diferentemente das constituições liberais, que estabeleciam poucos direitos e privilegiavam o desenho de instituições políticas voltadas a permitir que cada geração pudesse fazer as suas próprias escolhas substantivas, por intermédio da lei e de políticas públicas". VIEIRA, Oscar Vilhena, op. cit, p. 443. 
Observamos que considerar a judicialização da política como um fenômeno unilateral de transferência do poder legiferante ao judiciário constitui uma análise parcial do problema. Isso porque, se por um lado a judicialização constitui a causa da atribuição de confiança progressiva e latente no judiciário para tratar sobre questões morais; por outro, também é o resultado do encorajamento, por parte do povo e seus legislativos, de uma atuação judicial capaz de assegurar um amplo conjunto de valores humanos. Nessa perspectiva, existem boas razões pelas quais maiorias políticas delegam à verificação política do legislativo a tribunais, assim como bons argumentos que ilustram a disposição de tribunais para limitar e regular a autoridade parlamentar. Portanto, a judicialização pode ser reconhecida como uma via de mão dupla, pois a frequente interferência de tribunais nos processos políticos também evidencia que os atores políticos, ou grupos de ação política, possuem motivos para considerar a possibilidade de uma atuação judicial mais incisiva.

Sob essa ótica, é possível analisar a judicialização com enfoque em dois aspectos que John Ferejohn denominou de hipótese da fragmentação e hipótese dos direitos. O primeiro, como "uma crescente fragmentação do poder dentro dos poderes políticos, a qual limita a capacidade dos mesmos para legislar ou de ser o lugar onde a política é efetivamente formulada"16. Isso significa que, quando instituições políticas não podem agir, as pessoas tendem a procurar instituições que forneçam uma resposta que Ihes pareça adequada frente à concretização de uma demanda. Tribunais, usualmente, ocupam essa posição. A hipótese dos direitos "é a percepção de que se pode confiar nos tribunais (ou ao menos em alguns tribunais) para proteger uma ampla gama de valores importantes contra abuso político potencial"17. Evidenciamos, aqui, a ideia de que, a partir do momento que tribunais começaram a proteger direitos e liberdades pessoais, a oposição à postura expansiva do judiciário justificadamente diminui.

De fato, denotamos que: porque a comunidade passou a canalizar no poder judiciário a busca por efetivação de direitos não assegurados pelas instituições políticas é que a confiança no papel dos juízes resultou observada e, portanto, 16 FEREJOHN, John. Judicializando a Política, Politizando o Direito. In: MOREIRA, Luiz (Org.). Judicialização da Política. 1 ed. São Paulo: 22 Editorial, 2012, p. 80.

17 Ibidem, p. 81. 
a atuação mais ostensiva dos tribunais constitui a causa da confiança de uma resposta - considerada mais adequada - do poder judiciário. Por outro lado, a judicialização como consequência evidencia que: porque existem interesses em jogo é que o processo de judicialização da política se tornou interessante para os atores políticos e para juízes e tribunais, de forma a blindar eventual inobservância das regras do jogo e proteger interesses, aproveitando de uma situação de crise e/ou descrédito da política partidária.

Exploraremos esse fenômeno de mão dupla considerando três pontos importantes: a) a percepção distorcida da natureza estritamente jurídica atribuída ao judiciário e intrinsecamente política ao legislativo ocasiona posturas mais ou menos defensáveis da alocação do poder de legislar no judiciário e/ ou em tribunais constitucionais; b) o papel desempenhado pelas hierarquias organizacionais é crucial para destacar a dinâmica real do corpojudicial e, portanto, a maneira como os tribunais interagem com seu ambiente político; c) a posição de proeminência que o Supremo Tribunal Federal ocupa no sistema político brasileiro, especialmente no que se refere à representação política, evidencia, particularmente desde 2015, uma Corte em constante choque com o Congresso Nacional, com todas as consequências para a legitmidade democrática.

\section{O CARÁTER POLÍTICO DO PODER DE LEGIFERAÇÃO}

É natural atribuir às instituições explicitamente políticas (os poderes legislativo e executivo) e à instituição prioritariamente competente para a decisão sobre conflitos técnico-jurídicos (o poder judiciário) papéis distintos. John Ferejohn ${ }^{18}$ elucida essa associação elaborada pela teoria democrática clássica pontuando que à política corresponde as atividades do legislativo e, ao direito, as atividades do poder judiciário. Ou seja, na atuação do legislativo, a política é "natural", inevitável e legítima; em contraposição, o espaço do direito ou da aplicação da lei está reservado às salas de audiências, de modo que a controvérsia a respeito da interpretação da lei consiste precisamente em uma questão técnica de encontrar os princípios adequados para a resolução do litígio.

O espectro intrinsecamente político vislumbrado no poder legislativo diz respeito à tarefa propriamente encabeçada por ele: uma instituição que elabora 18 FEREJOHN, John. Judicializando a Política, Politizando o Direito. In: MOREIRA, Luiz (Org.). Judicialização da Política. 1 ed. São Paulo: 22 Editorial, 2012, pp. 73-74. 
leis que dizem respeito e vinculam a todos. Nesse sentido, a sociedade tem interesse em participar e monitorar os debates legislativos como forma de assegurar que seus direitos estejam minimamente representados nessa instância. Esse monitoramento da sociedade para com os representantes corresponde ao direito de participação e alude, sobretudo, à responsabilização que parlamentares possuem perante o eleitorado, cuja atuação envolve, além da eleição, a influência no direcionamento das políticas eventualmente adotadas. "Nesse sentido, esperase que a política de legiferação seja contenciosa, partidária e ideológica". ${ }^{19}$

Ao discorrer sobre o direito de participação, Jeremy Waldron ${ }^{20}$ elucida que a participação constitui o direito dos direitos, não exatamente por ser um direito moralmente superior, mas, precisamente, porque consiste em um direito apropriado no caso em que os indivíduos divergem sobre os direitos que possuem. Ora, se os indivíduos possuem deveres de cooperação em sociedade, se esses deveres são mais bem cumpridos quando dirigidos pelo Estado, em vez de individualmente e se os deveres dos indivíduos são os que orquestram a máquina do governo, então os indivíduos possuem o direito de decidir sobre os mecanismos de decisão que os controlam ${ }^{21}$.

Nessa esteira, o exercício do direito de participação deve ser avaliado a partir de uma descrição do que está em jogo no exercício do poder político. Waldron exemplifica com a seguinte situação: um determinado indivíduo possui um sentido de justiça e tem o necessário para participar das decisões em que seus direitos e dos demais estão em jogo; se este indivíduo é excluído da decisão, ele se sentirá menosprezado, não só porque sua noção de justiça não foi considerada, mas também porque não foi considerada em relação a direitos seus que estão em jogo ${ }^{22}$. Isso quer dizer que "eleger, monitorar, criticar e influenciar de qualquer outra forma os legisladores, e até mesmo opor-se a eles"23 integram o exercício do direito de participação, de modo que este indivíduo ou grupo, assim como os demais, deve ser tratado como igual nos assuntos que afetam seus interesses, seus direitos e suas obrigações. E essa atuação é identificada como, naturalmente, política.

19 Ibidem, p. 73.

20 WALDRON, Jeremy. Derecho y desacuerdos. Traducción José Luis Martí y Águeda Quiroga. Madrid: Marcial Pons, Ediciones Jurídicas y Sociales, S.A., 2005, p. 277.

21 Cf. WALDRON, Jeremy, op. cit., p. 280.

22 Cf. WALDRON, Jeremy, op. cit, p. 72.

23 FEREJOHN, John. Judicializando a Política, Politizando o Direito. In: MOREIRA, Luiz (Org.). Judicialização da Política. 1 ed. São Paulo: 22 Editorial, 2012, p. 73. 
Já na associação de que o poder judiciário atua conforme o direito, identificamos a concepção de que interferências políticas não são verificáveis $a$ priori. Isso porque a visão usualmente compartilhada circunscreve-se na ideia de que as autoridades jurídicas devem formar tribunais que sejam justos e imparciais e que interpretem as leis de acordo com um ordenamento jurídico previamente estabelecido, solucionando litígios específicos, de modo que os cidadãos não estão dispostos a influenciar a tomada de decisões de juízes como verificamos no processo de deliberação política no poder legislativo.

Essa identificação distorcida da neutralidade do poder judiciário repousa no próprio aspecto normativo direcionado à prática judicial. Os cidadãos podem promulgar leis por meio de seus representantes e praticar lobby junto às autoridades responsáveis pelas nomeações políticas com o objetivo de garantir que juízes competentes sejam nomeados para magistratura, por exemplo. Mas os cidadãos não podem pretender derrubar sentenças judicias ou, ainda, exercer pressão sob juízes para que julguem ações de uma determinada forma. E mesmo onde se submetem a eleições, causa certo estranhamento a ideia de juízes tendo que realizar campanhas eleitorais ou fazer promessas sobre o modo como decidirão ações futuras. ${ }^{24} \mathrm{Em}$ razão disso, ao direito e à atividade judicial liga-se a noção de um espaço em que a política - ou, pelo menos, a política partidária - não ocupa espaço.

A noção equivocada da correspondência do "político" ao poder legislativo, como instância parcial, intrinsecamente política e partidária, e do jurídico ao poder judiciário, como espaço de imparcialidade, neutralidade, independência e dotado de um corpo de sujeitos imunes às pressões políticas, gera o descompasso no plano normativo. Ou seja, a defesa de que devemos conferir a tribunais superiores e juízes, que possuem uma alta parcela de independência e frágil responsabilização de suas posturas (accountability), a competência para resolver questões morais e/ou filosoficamente controvertidas. Esse descompasso não só é passível de questionamentos no plano normativo como não é necessariamente verificável na realidade, já que o contexto em que Cortes Constitucionais estão inseridas, semelhante ao papel desempenhado pelo Supremo Tribunal Federal no Brasil, é conformado por investimentos políticos e conflitos interpretativos,

$24 \quad$ Ibidem, p. 74. 


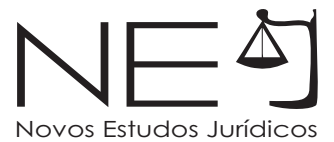

refletindo um contexto em que Cortes interagem com seu ambiente político, muitas vezes, de forma bastante partidária.

A prática judicial constitui o foco da análise política do pensamento jurídico e, conformedestacadoporAndreiKoerner ${ }^{25}$, integraalógicadoregimegovernamental ${ }^{26}$ e do regime jurisprudencial ${ }^{27}$. O desafio de buscar o contrabalanceamento ou fiscalização do poder, no objetivo de recuperar mecanismos de accountability e de eficiência do Judiciário brasileiro, por exemplo, integra os esforços da ciência política desde 1990, quando se iniciaram as reformas do Judiciário e do Estado. As pesquisas no STF destacaram, primeiramente, que tribunais teriam poderes amplos de controle e independência excessiva, levando ao aumento do número de litígios, aos problemas de eficiência e ao ativismo dos juízes, que utilizariam seus poderes para bloquear ações governamentais voltadas à modernização e à racionalização do Estado. O STF era visto como exercendo um real poder de fiscalização e as ações diretas de inconstitucionalidade (ADINs) seriam típicas dos problemas de acesso associados aos de independência e ineficiência. ${ }^{28}$

Outra abordagem, apontada por Luís Werneck Vianna ${ }^{29}$, considerou que houve a passagem de uma democracia majoritária, com a participação centrada em eleições e as decisões políticas no Parlamento, em que as normas e os princípios constitucionais seriam da ordem de garantias de direitos individuais, para uma democracia funcional, com a participação ampliada em diversos espaços da sociedade civil e do Estado, em que as normas constitucionais seriam a formulação de objetivos comuns voltados à promoção de direitos individuais e coletivos. $O$ maior protagonismo dos tribunais em relação a temas sociais e políticos seria positivo para a maior efetividade dos direitos e o fortalecimento da democracia.

A associação do "político" ao legislativo e do "jurídico" ao direito implica a percepção de que as atividades legislativa e judiciária devem ser conduzidas de

25 KOERNER, Andrei. Ativismo Judicial. In: Novos estudos - CEBRAP, DOSSIÊ: 25 ANOS DA CONSTITUIÇÃO DE 1988, n. 96. São Paulo, july 2013, pp. 76-77.

26 Regime governamental diz respeito à articulação geral, realizada pelas instituições políticas, das estratégias de poder de uma formação social e indica a maneira pela qual se programa e reflete a direção política da sociedade e a condução dos indivíduos. Ibidem, p. 76.

27 Regime jurisprudencial refere-se à maneira pela qual, articulada a um regime governamental, a prática judicial formula problemas, doutrinas e conceitos num esquema interpretativo e um repertório de soluções jurídicas. Ibidem, p. 76.

28 KOERNER, Andrei, op. cit., p. 75.

29 VIANNA, Luís Werneck e outros. A judicialização da política e das relações sociais no Brasil. Rio de Janeiro: Revan, 1999. 
maneira separada, respeitando princípios distintos e que a atividade política pode e deve estar circunscrita no poder legislativo. Essa visão, contudo, é reconhecida como simplista demais. Tanto a legiferação administrativa quanto a judicial é inevitável e justificadamente politizada e "nada em nenhuma dessas áreas políticas as torna exclusivamente adequadas à determinação judicial em lugar da legislativa" ${ }^{30}$. Isso porque os tribunais agem em parte porque os legislativos não podem agir, ou, quando podem, agem de forma inapropriada.

O debate acerca do aspecto jurídico ou político da atividade judicial, mais especificamente da jurisdição constitucional, foi a pedra de toque que emplacou as discussões entre Carl Schmitt e Hans Kensen relativamente ao Supremo Tribunal dos Estados Unidos. Nessa oportunidade, Schmitt denomina a corte americana como um estado judicial ${ }^{31}$ na medida em que ela interpreta de forma autoritária conceitos como propriedade, valor e liberdade. A principal característica dessa Corte, de acordo com o autor, "reside no fato de que ela, com a ajuda de pontos de vista básicos e princípios gerais, os quais só podem ser abusivamente qualificados de 'normas', examina a retidão e a racionalidade de leis e, por conseguinte, dado o caso, trata uma lei como não-aplicável"32. Esta Corte, portanto, apresenta-se guardiã de uma ordem social e econômica perante o Estado; um poder transcendental perante o Estado, de acordo com R. Gneist. ${ }^{33}$

Kelsen explana que, se enxergamos "o político" na resolução de conflitos de interesses, na "decisão" - usando a terminologia de Schmitt - encontramos em toda sentença judiciária, em alguma medida, um elemento decisório, um elemento de exercício de poder. À vista disso, a visão de que "somente a legislação seria política é tão errônea quanto aquela segundo a qual apenas a legislação seria criação produtiva do direito, e a jurisdição, porém, mera aplicação reprodutiva"34. Para o autor, trata-se de duas variantes de um mesmo erro, pois, na medida em que o legislador autoriza o juiz a avaliar, dentro de certos limites, interesses contrastantes entre si, e decidir conflitos em favor de um ou outro, está conferindo um poder de criação do direito e, portanto, um poder que dá à função judiciária

30 FEREJOHN, John. Judicializando a Política, Politizando o Direito. In: MOREIRA, Luiz (Org.). Judicialização da Política. 1. ed. São Paulo: 22 Editorial, 2012, p. 76.

31 SCHMITT, Carl. O Guardião da Constituição. Belo Horizonte: Del Rey, 2007, p. 20.

32 Ibidem, p. 21.

33 Ibidem, p. 22.

34 KELSEN, Hans. Jurisdição Constitucional. São Paulo: Martins Fontes, 2003, p. 251. 
o mesmo caráter "político" que possui a legislação. Porém, o autor adverte que a questão não deve ser colocada como um problema conceitual de jurisdição, mas sim como um problema sobre a melhor configuração da função desta jurisdição. Caso desejemos restringir o poder dos tribunais, e, assim, o caráter político da sua função, devemos então limitar o máximo possível a margem de discricionariedade que as leis concedem à utilização daquele poder ${ }^{35}$.

Nesse sentido, continua apropriada a objeção democrática levantada por Carl Schmitt de assumirmos como aproblemática a atribuição da competência para garantia da Constituição, sem maiores balizas, a um tribunal constitucional. Essa reflexão pode ser corroborada especialmente se considerarmos dois fatores: o primeiro, porque a decisão sobre qual norma geral deve ser aplicada em detrimento de outra é política e, consequentemente, a argumentação judicial nesses casos é também política; a segunda, porque a legislação judicial positiva (quando juízes criam leis em razão da abstenção do legislativo em fazê-lo), elaborada por um órgão judicial independente e isolado, gera dificuldade de controle.

\section{A LEGITIMIDADE DA LEGIFERAÇÃO JUDICIAL}

Usualmente, a política partidária contenciosa está inevitavelmente associada ao exercício do poder legiferante e, sendo assim, um tribunal, ao exercer a função de legislador positivo, não está imune à pressões políticas. Quando normas gerais são criadas, é possível que haja discordância sobre seu conteúdo e esse impasse não está adstrito às partes litigantes apenas. Ou seja, a disputa entre a divergência de entendimentos sobre o conteúdo de uma norma "é intrinsecamente política no sentido de que a escolha de uma norma ou interpretação em detrimento de outra deve ser justificável de alguma forma para aqueles que são afetados por tal norma"36.

Para Ferejohn:

A argumentação judicial nunca é expressa em termos partidários,

$35[$ [...] normas constitucionais a serem aplicadas por um tribunal constitucional, sobretudo as que definem o conteúdo de leis futuras - como as disposições sobre direitos fundamentais e similares - não devem ser formuladas em termos demasiado gerais, nem devem operar com chavões vagos como "liberdade", "igualdade", "justiça", etc. Do contrário existe o perigo de uma transferência de poder - não previsto pela Constituição e altamente inoportuno do Parlamento para uma instância externa a ele, a qual pode tornar-se o expoente de forças políticas totalmente distintas daquelas que se expressam no Parlamento. KELSEN, Hans. Jurisdição Constitucional. São Paulo: Martins Fontes, 2003, pp. 262-263.

36 FEREJOHN, John. Judicializando a Política, Politizando o Direito. In: MOREIRA, Luiz (Org.). Judicialização da Política. 1 ed. São Paulo: 22 Editorial, 2012, p. 77. 
mas discussões sobre quais normais deveriam ser adotadas são, não obstante, políticas. Essas discussões dizem respeito à maneira como os textos legais e os julgamentos anteriores devem ser entendidos, ou ao que a Constituição, ou alguma concepção de justiça, exige. Independentemente do modo como são formuladas, essas disputas dizem respeito às normas que devem governar a vida dos cidadãos, e todos têm interesse em ver como são decididas ${ }^{37}$.

Existem boas razões pelas quais podemos argumentar que certos tipos de leis sejam criados pelo judiciário ou pelo legislativo. Isso significa, também, que há razões diferentes para interesses e matérias em jogo diferentes, tomadas como referência em instituições diferentes. Portanto, "transferir a legiferação para tribunais e órgãos governamentais, quanto a essas questões, tem o efeito de alterar os tipos de considerações - os tipos de justificações deliberativas que entram na escolha de políticas alternativas". ${ }^{38}$

O que estamos a afirmar é que a política tende a seguir a legislação e, aqui, encontramos um fato empírico - do que observamos no plano da realidade - e considerações normativas - de como desejamos que seja, uma vez que a elaboração de leis diz respeito a todos que estão submetidos a elas e, portanto, todos devem poder influenciar em seus processos. Nesse sentido, não há algo de errado no fato de a legislação judicial possuir aspectos políticos; esperamos, contudo, que a política concernente ao legislativo seja diferente da política identificável no judiciário. Dessa forma, "o poder de legislar deve estar submetido à contestação e à deliberação política daqueles a quem as normas afetam. A configuração da política judicial, contudo, é e deve em certos pontos ser diferente daquela que circunda os poderes políticos". ${ }^{39}$

A dificuldade de estabelecermos parâmetros de controle na legislação elaborada por um órgão judicial independente e isolado assenta-se na fragilidade de encontrarmos uma justificação popular nesse espaço. Mesmo que estejam confortáveis com o fato de políticos nomearem juízes, os cidadãos não estão acostumados a responsabilizar juízes por suas ações na magistratura ${ }^{40}$. Assim,

40 "Diferentemente do legislativo, espera-se que o judiciário participe de um processo deliberativo para encontrar ou para moldar normas gerais. Mais especificamente, ao menos no nível recursal onde tal legiferação ocorre de 
"um retrato melhor do papel legislativo de tribunais em uma sociedade democrática enfatizaria que a legitimidade da legiferação judicial está baseada em seu caráter deliberativo. Desse ponto de vista, a principal característica do processo legislativo judicial surge da fraqueza de suas credenciais democráticas". ${ }^{41}$

As últimas décadas denotam que nos países europeus as garantias da independência do judiciário foram fortalecidas. Países pertencentes à tradição latina - Itália, França, Espanha e Portugal - sofreram uma mudança mais acentuada, e isso ocorreu não só no cenário institucional do judiciário, mas também no aumento do desempenho de tribunais no papel na verificação dos ramos políticos. ${ }^{42}$ Sobre o assunto, são assertivas as considerações de Carlo Guarnieri acerca da garantia da independência judicial, cujo conceito carrega um espectro de ambiguidade. Por um lado, a independência judicial é entendida como a independência institucional, isto é, como as garantias que os juízes desfrutam frente aos ramos políticos do governo. Por outro, o termo refere-se ao comportamento dos juízes, isto é, à sua independência no tribunal. No entanto, conforme destacado pelo autor: "se, como regra geral, para se comportar de forma independente, um juiz precisa ser independente das partes no caso (e, portanto, também do executivo), não se segue que os juízes institucionalmente independentes se comportem automaticamente de maneira independente". ${ }^{43}$

Para obter um controle efetivo do modo como o poder político é exercido, os juízes devem ser independentes, mas também capazes de intervir em casos significativos. Esse dilema nos direciona à compreensão de que, para avaliar o papel do sistema judiciário como um controle político, não só o status do judiciário deve ser levado em consideração; também é fundamental considerar a estrutura do sistema judicial ${ }^{44}$. Destarte, a fim de analisar o papel das cortes na forma mais explícita, os tribunais devem oferecer justificações arrazoadas tanto para suas decisões quando para mudanças doutrinárias. Na medida em que se espera que os tribunais forneçam razões, eles são responsabilizáveis por suas decisões. Eles não são, é claro, responsabilizáveis da mesma maneira que as autoridades eleitas. Uma decisão mal arrazoada não fará com que o juiz seja removido da magistratura. Mas a finalidade daquela decisão - se ela será recorrida ou anulada - e o seu alcance, por meio de quaisquer normas que se intencionasse instituir com ela, podem ser limitados por outros juízes, juristas ou autoridades eleitas. Decisões mal justificadas tendem a não ter impacto extensivo". FEREJOHN, John. Judicializando a Política, Politizando o Direito. In: MOREIRA, Luiz (Org.). Judicialização da Política. 1 ed. São Paulo: 22 Editorial, 2012, p. 79.

41 Ibidem, p. 78.

42 Cf. GUARNIERI, Carlo. Courts as an instrument of horizontal accountability. In: MARAVALL, José Maria. PRZEWORSKI, Adam (orgs) Democracy and the rule of law, p. 224.

43 GUARNIERI, Carlo, op. cit., p. 223. (Tradução nossa).

44 Cf. GUARNIERI, Carlo, op. cit., p. 225. (Tradução nossa). 
verificação política é preciso levarmos em conta como se estruturam os sistemas judiciários e no que esse desenho institucional resulta no papel mais ativo de tribunais na política de legiferação.

\title{
4. A INSTITUCIONALIZAÇÃO DE TRIBUNAIS CONSTITUCIONAIS E OS REFLEXOS NA ESTRUTURAÇÃO DOS SISTEMAS JUDICIÁRIOS
}

Após a Segunda Guerra Mundial, observamos um movimento de restrições impostas a maiorias parlamentares, de modo que a visão tradicional, segundo a qual a democracia implica o domínio da maioria sob a forma de supremacia parlamentar, passou por uma crescente crítica, conforme aponta Carlo Guarnieri:

\begin{abstract}
Na Europa desde a Segunda Guerra Mundial, os regimes democráticos incorporaram cada vez mais constrangimentos substanciais ao que a maioria parlamentar pode fazer. Não só a autoridade pública deve ser exercida dentro das regras gerais, mas os cidadãos são considerados como titulares de direitos fundamentais, cujo exercício deve permanecer fora da vontade da maioria. Portanto, submeter o desempenho de funções públicas ao escrutínio de juízes independentes torna-se um controle efetivo e essencial do exercício do poder político, garante a supremacia da lei e garante os direitos dos cidadãos ${ }^{45}$.
\end{abstract}

Segundo Leonardo Avritzer e Marjorie Corrêa Marona, o processo de constitucionalização das democracias contemporâneas envolve especialmente o fenômeno da reconstrução dos países derrotados na Segunda Guerra (Japão, Itália e Alemanha), uma vez que "nos legou um modelo de controle de constitucionalidade das leis que permite que se estabeleça um diálogo consistente, no campo dos direitos, capaz de avançar reflexões acerca do acesso à justiça ou das lutas de cidadania, especialmente em face de sociedades marcadas por diferenciações em termos de classe". ${ }^{46}$ Nesse ponto, portanto, é útil reconhecer a influência dos debates em torno da constitucionalização da vida política, que se desenrola na Europa, em meados do século XX.

É nesse contexto europeu, mais precisamente entre as duas grandes guerras, que Hans Kelsen propõe a adoção de tribunais constitucionais. A conjuntura perpassava por uma quebra de paradigmas hermenêuticos, em que enaltecíamos o particular em detrimento do universal ${ }^{47}$. Essa perspectiva gerou a insuscetibilidade de submissão de uma interpretação a outra, mas também

45 GUARNIERI, Carlo, op. cit., p. 223. (Tradução nossa).

46 AVRITZER, Leonardo; MARONA, Marjorie Corrêa. Judicialização da política no Brasil: ver além do constitucionalismo liberal para ver melhor. In: Revista Brasileira de Ciência Política, n 15. Brasília, set. - dez. de 2014, pp. 76-77.

47 "O primeiro tribunal constitucional em território europeu foi previsto pela Constituição austríaca de 1920, por obra e influência de Hans Kelsen, tendo gerado enorme polêmica no continente." AVRITZER, Leonardo; MARONA, Marjorie Corrêa, op. cit., p. 76. 
garantiu que não houvesse supremacia cultural de um país sobre o outro, o que se institucionalizava com a supremacia parlamentar, vez que cabia aos parlamentos a representação das distintas visões de mundo. ${ }^{48}$

Foi no contexto de um ato político - decorrente da vitória norte-americana na Segunda Grande Guerra - que os tribunais constitucionais institucionalizaramse. A jurisdição constitucional obteve aceitação rápida e generalizada na Itália e em outros países da Europa, especialmente em razão do fator da expansão do conjunto de direitos a serem protegidos pelos tribunais constitucionais. A necessidade de se confiar a um tribunal constitucional a garantia da atividade legiferante na proteção de valores fundamentais foi sentida, de maneira mais acentuada, pela Itália e Alemanha inicialmente, uma vez que os processos de legiferação nesses países foram extremamente enfraquecidos no tocante à observância de direitos humanos em razão dos regimes facista e nazista. Suspeitava-se não apenas do legislativo, mas também de tribunais ordinários na tarefa de barrar a legislação autoriária. ${ }^{49}$ É por isso que "a instituição de novos tribunais constitucionais, que teriam o poder de derrubar leis, mas que seriam independentes do próprio judiciário, foi parte da resposta a essa dupla circunstância de desconfiança quanto ao legislativo e ao sistema judiciário ordinário". 50

No Brasil, após 1985, com o fim da ditadura militar, os direitos civis foram restabelecidos; e, após 1988, com a promulgação da nova Constituição, os direitos políticos adquiriram uma amplitude nunca antes experimentada pelo povo brasileiro. A constitucionalização dos regimes políticos, a partir dos intrumentos de revisão judicial e do controle de constitucionalidasde de leis e atos normativos, chegou ao Brasil com a redemocratização, alterando-se o padrão de relação entre as tradicionais instituições políticas representativas e o Judiciário e/ou cortes constitucionais $^{51}$. Esse fenômeno ocasinou uma enorme autonomia do Poder Judiciário no novo quadro constitucional.

Ao analisar as reformas que têm alterado as posições de juízes europeus a fim de considerar algumas mudanças que têm afetado o sistema judicial,

48 Cf. VALLINDER, Torjbjorn; HIRSCHL, Ran; FOREJOHN, John; etc. Judicialização da Política / MOREIRA, Luiz (Org.). Editorial: São Paulo, 2012, p. 6.

49 Cf. FEREJOHN, John. Judicializando a Política, Politizando o Direito. Op. cit., p. 82.

50 Ibidem, p. 82.

51 Cf. AVRITZER, Leonardo; MARONA, Marjorie Corrêa. Judicialização da política no Brasil: ver além do constitucionalismo liberal para ver melhor. In: Revista Brasileira de Ciência Política, n 15. Brasília, set. - dez. de 2014, pp. 81-82. 
Carlo Guarnieri elenca elementos ${ }^{52}$ que influenciam a concreta posição de juízes individuais e permitem verificar o escopo das gradações de independência judicial (externa ou interna) ${ }^{53}$, discorrendo sobre a organização judicial do continente. A justificativa se encontra, precisamente, no fato de que "todos esses elementos influenciam a posição concreta dos juízes individuais e permitem uma avaliação do alcance real do gradiente interno e externo da independência judicial" ${ }^{54}$. $E$, em sua visão, a intervenção externa que juízes sofrem ${ }^{55}$, "embora com diferentes formas, representou o canal institucional mais importante que liga o sistema judiciário ao sistema político" ${ }^{\prime \prime 6}$.

Destaque deve ser conferido aos Conselhos Superiores do Judiciário nos países de origem latina, instituições criadas com o intuito de fortalecer a independência dos tribunais, constituindo um elemento crucial para entender como as relações entre os tribunais e as políticas evoluíram nesses países. Para o autor, "o nível de independência tende a ser maior quando membros judiciais recebem a maioria dos assentos e são eleitos diretamente pelos seus colegas. Do mesmo modo, as garantias de que gozará o Judiciário serão mais amplas quando as funções confiadas aos Conselhos Superiores forem mais amplas". ${ }^{57}$ Deste ponto de vista, a Itália é, sem dúvida, o país que experimentou a mudança mais radical.

Alguns exemplos podem ser tomados como referência na estruturação de Conselhos Superiores ${ }^{58}$ na Itália, Espanha, Portugal e França, em que evidenciamos que as mudanças introduzidas neste sistema no período do pós-guerra aumentaram, no geral - embora com uma extensão variada -, a independência institucional do judiciário ${ }^{59}$. Não só a independência externa foi reforçada, mas o

52 Para avaliarmos as garantias da independência que os juízes desfrutam, é preciso considerarmos o conjunto do sistema institucional do judiciário (nomeações, transferências, procedimentos disciplinares e padrões de carreira).

53 A independência externa "refere-se às relações entre o poder judiciário e os outros ramos do governo"; por sua vez, a independência interna "concentra-se em garantias pessoais destinadas a proteger os indivíduos de pressões indevidas provenientes da organização, nomeadamente de outros juízes”. (Shetreet 1985: 637-8). GUARNIERI, Carlo. Courts as an instrument of horizontal accoutability, in MARAVALL, José Maria. PRZEWORSKI, Adam (orgs) Democracy and the rule of law, p. 225. (Tradução nossa).

54 Ibidem, p. 225. (Tradução nossa).

55 A "revisão dos pares", um dispositivo típico de controle social em organizações profissionais, é substituída por avaliações formais e escritas elaboradas por juízes de alto escalão. Além disso, o processo de tomada de decisão que leva a promoções muitas vezes vê a participação de outros atores, colocados fora do sistema judicial: especialmente o executivo, isto é, o Ministério da Justiça. Ibidem, p. 226

56 Ibidem, p. 226. (Tradução nossa).

57 Ibidem, p. 226. (Tradução nossa).

58 Para aprofundamento, consultar: GUARNIERI, Carlo, op. cit., pp. 226-230.

59 Sobre os Conselhos Superiores, "eles fornecem uma arena para as contínuas interações entre o judiciário e a classe política, suas decisões são muitas vezes o produto de trocas entre facções judiciais e representantes de partidos políticos 


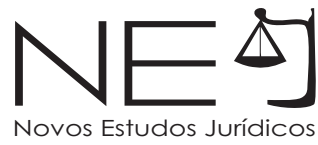

gradiente interno foi reforçado, enfraquecendo o papel tradicional desempenhado por níveis mais elevados nestes judiciários.

Observamos que a capacidade de um judiciário burocrático para sustentar o Estado de Direito pode ser questionada e implica um risco evidente para a democracia, especialmente na ocasião em que a interpretação das leis se torna o domínio exclusivo de burocratas autonomeados ${ }^{60}$. Esse é o exemplo que os países europeus latinos nos emprestam, em que a necessidade de fortalecer a independência judicial os levou a transferir cada vez mais poderes executivos para órgãos colegiados, como os Conselhos Superiores. No entanto, quando os juízes controlam os conselhos, os interesses corporativos tendem a ser privilegiados e, às vezes, o poder das facções judiciais se torna uma ameaça à independência do juiz individual. Por outro lado, quando os membros políticos ou parlamentares são a maioria, não é um ganho tão grande quanto à situação anterior de predominância executiva. ${ }^{61}$

Nas palavras de Carlo Guarnieri:

A independência judicial não pode tornar-se uma barreira para uma avaliação efetiva das qualificações profissionais dos juízes. Acima de tudo, não deve se divorciar do poder judicial do sistema político. Não é só que o significado das decisões judiciais nas democracias contemporâneas exige que os juízes sejam feitos de alguma forma responsáveis. Há mais do que isso. À medida que o poder judicial se expande, um incentivo é criado para grupos políticos pressionarem o judiciário, explorando todos os canais de influência disponíveis. Por ser impossível fazer desaparecer a política, parece mais sensato canalizar a pressão política de maneira institucional. Desta forma, a forma como a influência política é exercida pode ser melhor exposta e consequentemente limitada, enquanto o poder judicial também é verificado: para evitar abusos, todo o poder deve ser verificado e o judiciário não é exceção ${ }^{62}$.

No mesmo sentido são as considerações de John Ferejohn, para quem "a composição da magistratura e do funcionalismo jurídico em geral é permeável à influência dos mesmos grupos de interesse". ${ }^{63} \mathrm{E}$ isso podemos observar

(por exemplo, quando as nomeações para posições-chave devem ser feitas)." Ibidem, p. 238. (Tradução nossa).

61 Ibidem, p. 239. (Tradução nossa).

62 Cf. GUARNIERI, Carlo, op. cit., p. 240. (Tradução nossa).

63 FEREJOHN, John. Judicializando a Política, Politizando o Direito. In: MOREIRA, Luiz (Org.). Judicialização da Política. 1 ed. São Paulo: 22 Editorial, 2012, p. 92. 
tanto na estrutura dos tribunais constitucionais europeus quanto do tribunal estadunidense. Este, como observado por Tocqueville, é particularmente aberto à formação e à proliferação de associações e grupos de interesse ${ }^{64}$, sendo que essas organizações têm sido eficientes em buscar seus interesses políticos dentro do terreno legal no qual a deliberação e a argumentação são o modo como normas gerais são adotadas e modificadas ${ }^{65}$.

Os tribunais europeus, por sua vez, são menos suscetíveis ao escrutínio público do que os norte-americanos. Isso porque a deliberação ocorre em segredo, os acórdãos são proferidos per curiam (do tribunal) e, muitas vezes, não permitem a publicação de votos vencidos. Para Forejohn, essa estrutura resulta em menos chances de que grupos de interesse visualizem como juízes sentenciam ou votam e, portanto, restam reduzidas as críticas ou os elogios por suas ações na magistratura. Nesse sentido, "embora os tribunais constitucionais europeus possam ser tão políticos quanto os tribunais estadunidenses, no sentido de participarem da legiferação de maneira não submetida ao controle do legislativo, eles são muito menos partidários, e sua ideologia tende a ser centrista"66.

\section{A INTERFERÊNCIA DO SUPREMO TRIBUNAL FEDERAL NA VIDA} POLÍTICA NACIONAL

No Brasil, a expansão da autoridade de tribunais recebeu contornos bem acentuados que incorporaram o que Oscar Vilhena Vieira ${ }^{67}$ denominou de Supremocracia. A partir desse termo, Vieira destaca, com referência a dois aspectos, a singularidade do arranjo institucional judicial brasileiro. Primeiro,

64 À esquerda, a Associação Nacional para o Avanço de Pessoas de Cor, a Organização Nacional para Mulheres, o Conselho de Defesa de Recursos Nacionais, a União Norte-Americana de Liberdades Civis entre outros. À "direita", há a fundação Jurídica Pacifista, a Sociedade Federalista, entre outras. FEREJOHN, John, op. cit., p. 91.

65 Em sua pesquisa, Andrei Koerner também apresenta algumas proposições sobre as relações entre jurisprudência e política, ilustrando com referência à Corte Warren e à Corte Rehnquist. Em síntese, o autor conclui que: agentes situados em espaços institucionais distintos têm incentivos para cooperarem; a Corte reage de modos diversos aos incentivos, pois tem suas lógicas próprias de ação, agendas substantivas e prioridades; historicamente, a agenda das cortes não tem sido autogerada; não há sincronia ou relação causal, mas antes a sua convergência não linear e imperfeita entre realinhamento partidário e mudança jurisprudencial; o papel político da Suprema Corte é amplo e complexo, pois é mobilizada para decidir sobre questões críticas e suas respostas produzem impactos imprevistos; decisões judiciais podem gerar estratégias de resistência e contramobilização; há reversibilidade política dos modelos e técnicas de decisão; o contexto em que as cortes estão inseridas é conformado por investimentos políticos e conflitos interpretativos; há polivalência tática de doutrinas e conceitos jurídicos. KOERNER, Andrei. Ativismo Judicial. In: Novos estudos - CEBRAP, DOSSIÊ: 25 ANOS DA CONSTITUIÇÃO DE 1988, n. 96. São Paulo July 2013, pp. 77-79.

66 FEREJOHN, John. Judicializando a Política, Politizando o Direito. In: MOREIRA, Luiz (Org.). Judicialização da Política. 1 ed. São Paulo: 22 Editorial, 2012, p. 93.

67 VIEIRA, Oscar Vilhena. Supremocracia. In: REVISTA DIREITO GV, São Paulo, jul-dez de 2008, pp. 444-445. 
Supremocracia identifica a autoridade que o STF guarda em relação às demais instâncias do judiciário, ocupando o lugar de governar jurisdicionalmente o Poder Judiciário no Brasil; em um segundo enfoque, a expressão também identifica a expansão do STF em relação aos demais Poderes da República (Legislativo e Executivo), figurando a Corte como centro do sistema político.

De acordo com Vieira, o papel político do STF - que a partir de 1988 passou a acumular as funções típicas de um tribunal constitucional - foi reforçado com a EC n. 3/93, EC n. 45/05, bem como com a Lei n. 9.868/99 e Lei n. 9.882/99. Nesse sentido, o Supremo passou a exercer não somente a função de guardião da Constituição ou de protetor de direitos, mas também de criação de regras. Nesse desenho, o Supremo cumula o exercício de autoridade, característico da interpretação constitucional, com o exercício de poder. "Esta última atribuição, dentro de um sistema democrático, deveria ficar reservada a órgãos representativos, pois quem exerce poder em uma república deve sempre estar submetido a controles de natureza democrática." ${ }^{68}$

O desenho institucional desta Corte Suprema podemos identificar se observarmos a ambição constitucional fruto da Constituição de 1988 - que revestiu inúmeras matérias com roupagem constitucional e, portanto, reduziu sobremaneira o campo de liberdade conferido ao corpo político -, e a sua arquitetura institucional, que resultou em uma conferência de amplos poderes de guardião constitucional ao Supremo Tribunal Federal. Segundo Oscar Vieira, "foram atribuídas funções que, na maioria das democracias contemporâneas, estão divididas em pelo menos três tipos de instituições: tribunais constitucionais, foros judiciais especializados (ou simplesmente competências difusas pelo sistema judiciário) e tribunais de recursos de última instância."69

Sobretudo na última década, são muitos os exemplos que ilustram a expansão da capacidade do Supremo Tribunal Federal para interferir diretamente em questões que, até então, eram consideradas de natureza essencialmente política e que, por isso, competiam aos poderes executivo e legislativo. Para cada um dos muitos dos temas considerados relevantes na vida política nacional, cada vez mais parece ser suficiente identificar alguma controvérsia "interpretativa" sobre 68 Ibidem, p. 446.

69 Ibidem, p. 447. 
as regras (quando não princípios abstratos) que regulam a matéria para então concluir que a controvérsia em questão "reclama" a intervenção da Corte. Enfim, para cada conflito político efetivo, basta identificar um correspondente conflito "constitucional" para afirmar a legitimidade da interferência do tribunal, sem maiores preocupações com a intensidade da interversão. Particularmente desde 2015, desde o início da atual crise política que o país atravessa, é possível observar um Supremo Tribunal Federal em constante choque com o Congresso Nacional. ${ }^{70}$

No campo da representação política, por exemplo, o STF foi chamado a se pronunciar acerca da situação do ex-senador Delcídio do Amaral (PT-MS). A Ação Cautelar (AC) 4039, de relatoria do Ex-Ministro Teori Zavascki, julgada em 24 de novembro de 2015, versava sobre o requerimento formulado pelo Procurador-Geral da República de medidas restritivas de liberdade em face, dentro outros, do então Senador Delcídio do Amaral Gomez. Nessa oportunidade, o congressista foi preso com base em critério não previsto na Constituição. A decisão da turma se baseou no parágrafo $2^{\circ}$ do artigo 53 da Constituição Federal, o qual dispõe que parlamentares não podem ser presos, a não ser em casos de "flagrante de crime inafiançável"; nesse caso, os autos serão remetidos dentro de vinte e quatro horas à Casa respectiva, para que, pelo voto da maioria de seus membros, resolva sobre a prisão.

A situação de flagrância foi justificada pelo ministro relator por se tratar de crime permanente - fazer parte (integrar) crime organizado (art. $2^{\circ}$ da Lei $12.850 / 13)$. O crime permanente admite prisão em flagrante em qualquer momento de acordo com os artigos 302 e 303 do CPP. No que tange à inafiançabilidade, o crime organizado, em si, é afiançável; contudo, "quando presentes os motivos que autorizam a decretação da prisão preventiva", o crime se torna inafiançável (art. 324, IV, CPP). A interpretação da Constituição que preponderou no STF contempla a incidência do binômio crime permanente (integrar crime organizado) + situação de inafiançabilidade (motivo para decretação da prisão preventiva), resultando na admissibilidade da prisão em flagrante. Na hipótese de senador preso em flagrante, impõe-se urgentemente a apresentação de uma acusação formal pelo Procurador-Geral da República. A conversão da prisão em flagrante

70 "A marca desse período não tem sido apenas o de conflito, mas de ações e respostas inusitadas que, por sua vez, colocaram em xeque a autoridade e a legitimidade das instituições envolvidas". GLEZER, Rubens. SUPREMO EM PAUTA: Poderes em desequilíbrio Disponível em: <http://politica.estadao.com.br/noticias/geral,supremo-empauta-poderes-em-desequilibrio, 70001840100>. Acesso em: 12 dez. 2017. 


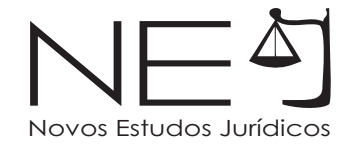

em prisão preventiva neste caso é sui generis, pois, na existência de fundamentos para prisão igualmente, deverá haver suporte suficiente para a denúncia. Neste caso, compete ao STF receber ou não a denúncia. Recebida a denúncia, o processo teria andamento normal, com a decisão do STF.

Outro exemplo digno de nota foi o pronunciamento do Supremo Tribunal Federal (STF) no caso do Ex-Presidente da Câmara dos Deputados Eduardo Cunha. Em 5 de maio de 2016, a Corte referendou a decisão do Ministro Teori Zavascki, proferida na Ação Cautelar (AC) 4070, que suspendeu Eduardo Cunha (PMDB-RJ) do exercício do mandato de deputado federal e, por consequência, da função de presidente da Câmara dos Deputados. Neste caso, o STF criou a figura da suspensão de mandato, inovando na decisão de afastamento do congressista, uma vez que foi apreendido sem que tivesse cometendo crime inafiançável em flagrante. Considerando que a Constituição Federal não prevê a suspensão do exercício do mandato de deputado, dispondo que parlamentares só serão presos em razão de flagrante de crime inafiançável - com a confirmação da Câmara ou do Senado -, qualquer medida alternativa à prisão deveria seguir esse mesmo rito, ou seja, exigibilidade de incidir em crime para o qual não caiba fiança, conferindo a possibilidade à Casa respectiva de confirmar a decisão. Ao aplicar a lei de medidas cautelares no caso do deputado Eduardo Cunha, criou-se uma incongruência entre a figura da suspensão de mandato e as garantias previstas na Constituição, pois quando um parlamentar sofre um processo criminal, ele pode ser preso, mas permanece com o mandato, já que a incidência de medidas cautelares não integra as hipóteses de perda de mandato previstas no art. 55 da Constituição Federal.

Mais recentemente, a Primeira Turma do Supremo Tribunal Federal também se pronunciou sobre a suspensão do mandato do Senador Aécio Neves (PSDBMG), quando decidiu, no julgamento de agravo na Ação Cautelar (AC) 4327, em 26 de setembro de 2017, por 6 votos a 5, afastá-lo do exercício de seu mandato, medida cautelar requerida pela Procuradoria-Geral da República (PGR) no inquérito em que o senador foi denunciado por corrupção passiva e obstrução de Justiça, com base nas delações premiadas da empresa J\&F. Nessa oportunidade, o STF reafirmou o poder de aplicar medidas cautelares, mas entendeu pela submissão da decisão judicial à Casa respectiva (Senado), novamente adotando 
posicionamento, estranho às garantias constitucionais, no sentido de restringir as imunidades parlamentares.

Esse cenário evidencia que o Supremo tem se sentido confortável para interferir no poder político do Legislativo, munindo-se de mecanismos estranhos a qualquer legislação, alegando reiteradamente que a excepcionalidade da forma de interpretar e aplicar os princípios e as regras do sistema constitucional corresponde à excepcionalidade do quadro ${ }^{71}$. A ausência de freios ao seu poder interfere sobremaneira no sistema de controle recíprocos incorporado na separação de poderes. Esse desenho institucional coloca claramente o Supremo em posição proeminente como arena do debate público. Nessa perspectiva, se consideramos que este protagonismo e esta liberdade do STF vêm fortalecer o Estado de Direito e o constitucionalismo, também devemos atentar para o fato consequente de que o controle da política pela jurisdição constitucional gera uma fragilidade do sistema representativo em responder as expectativas a ele direcionadas.

\section{CONSIDERAÇÕES FINAIS}

A prática de judicializar a política trouxe consigo todas as consequências para a legitimidade democrática, revelando um contexto no qual a jurisdição constitucional no Brasil detém majoritariamente o controle da política. Esse contexto traz à tona objeções de ordem normativa e empírica.

As instituições judiciais são instituições compostas por indivíduos dotados de racionalidade e altruísmo limitados, interesses e valores particulares, suscetibilidade à influência de grupos de pressão. Sendo assim, os agentes que integram as instituições judiciais de algum modo participam do processo de disputas políticas, o que limita drasticamente suas pretensões de figurarem como "terceiros imparciais" em relação aos conflitos políticos e sociais e de recorrerem a argumentos teóricos complexos, os quais demandam informação e expertise raramente acessíveis aos juristas, para revisar juízos legislativos.

A legitimidade da intervenção judicial em matérias politicamente controvertidas é questionada na medida em que é sustentada por um órgão judicial independente e isolado, cujo desenho institucional gera dificuldade de

71 STF. AÇÃO CAUTELAR 4039. Relator Ministro Teori Zavascki. DJ: 25/11/2015. STF, 2015, p. 38. Disponível em: http://www.stf.jus.br/portal/cms/verNoticiaDetalhe.asp?idConteudo=304788. Acesso em: 8 jan. 2018. 
controle. A expansão de um poder sem freios verificador da vida política nacional fragiliza a atividade legislativa representativa parlamentar e os conflitos políticos e sociais, que marcam exercício efetivo dos direitos políticos de participação.

A defesa de uma jurisdição constitucional mais "autorrestrita" pode ser um caminho menos ambicioso e mais realista frente ao panorama brasileiro atual. Uma jurisdição preocupada em intervir para fortalecer os processos políticos representativos e a participação cidadã das classes sociais subalternas, mas que evita meramente substituir as opções expressas nos processos representativos pelas opiniões, valores e interesses particulares das elites judiciais.

\section{REFERÊNCIAS DAS FONTES CITADAS}

AVRITZER, Leonardo; MARONA, Marjorie Corrêa. Judicialização da política no Brasil: ver além do constitucionalismo liberal para ver melhor. In: Revista Brasileira de Ciência Política, $\mathrm{n}^{\circ} 15$. Brasília, set. - dez. de 2014, pp. 76-77.

BARROSO, Luis Roberto. Judicialização, Ativismo Judicial e Legitimidade Democrática. In: (Syn)thesis, v. 5, n. 1, 2012.

BARROSO, Luis Roberto. Constituição, democracia e supremacia judicial: direito e política no brasil contemporâneo. In: RFD- Revista da Faculdade de Direito- UERJ, v. 2, n. 21, jan./jun. 2012.

BRASIL. Constituição (1988). Constituição da República Federativa do Brasil. Brasília, DF: Senado Federal, 1988.

ELSTER, Jon. Regla de Mayoría y derechos individuales. In: Agora: caderno de estúdios políticos, ano 4, n. 8, 1988, pp. 23-57.

ENGELMANN, Fabiano. Internacionalização e ativismo judicial: as causas coletivas. In: Lua Nova, São Paulo, 69: 123-146, 2006.

GLEZER, Rubens. SUPREMO EM PAUTA: Poderes em desequilíbrio Disponível em: $<$ http://politica.estadao.com.br/noticias/geral,supremo-em-pauta-poderes-emdesequilibrio,70001840100>. Acesso em: 12 dez. 2017.

HOLMES, Stephen. Constituições e constitucionalismo, in ASENSI, Felipe. PAULA, Daniel Giotti de (orgs). Tratado de Direito Constitucional, vol. 2, Rio de Janeiro: Elsevier, 2014, 577-608.

KELSEN, Hans. Jurisdição Constitucional. São Paulo: Martins Fontes, 2003.

KOERNER, Andrei. Ativismo Judicial. In: Novos estudos-CEBRAP, Dossiê: 25 anos da Constituição de 1988, n. 96. São Paulo July 2013, pp. 76-77. 
MACIEL, Débora Alves; KOERNER, Andrei. Sentidos da judicialização da política: duas análises. Disponível em: <http://www.scielo.br/pdf/\%0D/ln/n57/a06n57.pdf>. Acesso em: 11 dez. 2017.

MOREIRA, Luiz, org. Judicialização da Política. 1. ed. São Paulo: 22 Editorial, 2012.

MARAVALL, José Maria. PRZEWORSKI, Adam (orgs). Democracy and the rule of law. Cambridge: Cambridge University Press, 2003.

SHAPIRO, Sweet. On Law, Politics, and Judicialization. New York: Oxford University Press, 2002. SCHMITT, Carl. O Guardião da Constituição. Belo Horizonte: Del Rey, 2007.

STF. AÇÃO CAUTELAR 4039. Relator Ministro Teori Zavascki. DJ: 25/11/2015. STF, 2015, p. 38. Disponível em: http://www.stf.jus.br/portal/cms/verNoticiaDetalhe.asp?idConteudo=304788. Acesso em: 8 jan. 2018.

TATE, C. Neal; VALLINDER, Torbjorn. The Global Expansion of Judicial Power. New York: New York University Press, 1995.

VERBICARO, Loiane Prado. Um estudo sobre as condições facilitadoras da judicialização da política no brasil. In: Revista Direito GV, jul.-dez. 2008, São Paulo, p. 389-406.

VERONESE, Alexandre. A judicialização da política na América Latina: panorama do debate teórico contemporâneo. In: Escritos - três - Revista da Fundação Casa de Rui Barbosa, ano 3, n. 3, 2009.

VIEIRA, Oscar Vilhena. Supremocracia. In: Revista Direito GV, São Paulo, jul-dez de 2008, p. 441-464.

WALDRON, Jeremy. A Essência da Oposição ao Judicial Review, in BIGONHA, Antonio Carlos Alpino; MOREIRA, Luiz (orgs). Legitimidade da jurisdição Constitucional. Rio de Janeiro: Lumen Juris, 2010, pp. 93-157.

WALDRON, Jeremy. Derecho y desacuerdos. Traducción José Luis Martí y Águeda Quiroga. Madrid: Marcial Pons, Ediciones Jurídicas y Sociales, S.A., 2005.

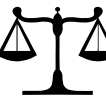

Recebido em: abril/2018

Aprovado em: abril/2018 